\title{
Degradation of buried ice and permafrost in the Veleta cirque (Sierra Nevada, Spain) from 2006 to 2013 as a response to recent climate trends
}

\author{
A. Gómez-Ortiz ${ }^{1}$, M. Oliva ${ }^{2}$, F. Salvador-Franch ${ }^{1}$, M. Salvà-Catarineu ${ }^{1}$, D. Palacios ${ }^{3}$, J. J. de Sanjosé-Blasco ${ }^{4}$, \\ L. M. Tanarro-García ${ }^{3}$, J. Galindo-Zaldívar ${ }^{5}$, and C. Sanz de Galdeano ${ }^{6}$ \\ ${ }^{1}$ Department for Physical and Regional Geography, University of Barcelona, Montalegre, 6-8, \\ 08001 Barcelona, Catalonia, Spain \\ ${ }^{2}$ Institute of Geography and Spatial Planning, University of Lisbon, Alameda da Universidade, 1600-214, \\ Lisbon, Portugal \\ ${ }^{3}$ Department for Regional and Physical Geography, Complutense University of Madrid, 28040 Madrid, Spain \\ ${ }^{4}$ Departmento de Expresión Gráfica, University of Extremadura, 10071 Cáceres, Spain \\ ${ }^{5}$ Department of Geodynamics, University of Granada, Spain \\ ${ }^{6}$ Instituto Andaluz de Ciencias de la Tierra, CSIC, University of Granada, Spain \\ Correspondence to: M. Oliva (oliva_marc@yahoo.com)
}

Received: 17 January 2014 - Published in Solid Earth Discuss.: 11 April 2014

Revised: 8 July 2014 - Accepted: 10 July 2014 - Published: 10 September 2014

\begin{abstract}
The Veleta cirque is located at the foot of the Veleta peak, one of the highest summits of the Sierra Nevada National Park (southern Spain). This cirque was the source of a glacier valley during the Quaternary cold periods. During the Little Ice Age it sheltered a small glacier, the most southerly in Europe, about which we have possessed written records since the 17 th century. This glacier still had ice residues until the mid-20th century. This ice is no longer visible, but a residue persists along with discontinuous permafrost trapped under strata of rock blocks that make up an incipient rock glacier.

From 2006 to 2013, this rock glacier was monitored by measurement of the temperature of the active layer, the degree of snow cover on the ground, movements of the body of the rock glacier and geophysical prospection inside it. The results show that the relict ice and trapped permafrost have been steadily declining. The processes that explain this degradation occur in chain, starting from the external radiation that affects the ground in summer, which is when the temperatures are higher. In effect, when this radiation steadily melts the snow on the ground, the thermal expansive wave advances into the heart of the active layer, reaching the ceiling of the frozen mass, which it then degrades and melts. In this entire linked process, the circulation of meltwaters ful-
\end{abstract}

fils a highly significant function, as they act as heat transmitters. The complementary nature of these processes explains the subsidence and continuous changes in the entire clastic pack and the melting of the frozen ceiling on which it rests. This happens in summer in just a few weeks.

All these events, in particular the geomorphological ones, take place on the Sierra Nevada peaks within certain climate conditions that are at present unfavourable to the maintenance of snow on the ground in summer. These conditions could be related to recent variations in the climate, starting in the mid-19th century and most markedly since the second half of the 20th century.

The work and results highlight the climate sensitivity of the peaks of the Sierra Nevada to the effect of climate change and its impact on the dynamics of ecosystems, which is a benchmark for evaluating the current evolution of landscapes of Mediterranean high mountains. 


\section{Introduction}

Recent decades have seen an exponential increase in studies of high-latitude and wet mid-latitude mountains, centring on the repercussions that the recent climate trend to increasing temperature is having on the earth's ecosystems (Yang et al., 2010), with particular emphasis on the geomorphological repercussions of permafrost degradation on these environments. The great many settlements and infrastructures present in these areas have been affected by the warming experienced in recent decades (Nelson et al., 2001, 2002; Lawrence et al., 2008). This increase has been most marked in areas of cold permafrost compared to areas of warm permafrost (Christiansen et al., 2010; Romanovsky et al., 2010).

However, there have been few researchers who have attempted to monitor the geomorphological processes in wet mid-latitude mountain ranges, where the presence of permafrost is marginal or residual (Ishikawa, 2003; Löffler et al., 2006; Gadek and Leszkiewicz, 2010). In the semi-arid environments of the high mountains of the Mediterranean Alpine fringe, permanent frozen ground is restricted to specific sites on the highest north-facing mountains. As there are so few of these sites, winter facilities and buildings that might be affected by a change in the state of the underlying soil in practice do not exist. This geographical context means that research has focused more on environments with seasonal frozen ground, especially the distribution of periglacial processes, their dynamics under existing climate conditions and the ground's thermal regime (e.g. Oliva et al., 2008, 2009).

In the case of the Iberian Peninsula, thermal regimes of permafrost in the ground have only been found in three massifs: probably in the Picos de Europa (Ruiz Fernández, 2013), at various Pyrenean sites (Serrano et al., 2001; Lugon et al., 2004; Serrano et al., 2009) and Sierra Nevada, the massif that this study concentrates on (Gómez-Ortiz et al., 2001, 2004).

The high peaks of Sierra Nevada, concretely its highest northerly cirques, were home to the most southerly glaciers in Europe during the Little Ice Age (LIA; Gómez-Ortiz et al., 2012b). The thermal rise since the last decades of the 20th century was measured at $0.93^{\circ} \mathrm{C}$ in Sierra Nevada (Oliva and Gómez-Ortiz, 2012), which has brought about the disappearance of these final redoubts of glaciers in the massif. The Veleta cirque, possibly the best-studied site in Sierra Nevada, is particularly interesting (Gómez-Ortiz et al., 2013). The references to its environmental evolution from the 17th century on are common and enable us to reconstruct the presence of a glacier at its heart and to chart its gradual disappearance since the first decades of the 19th century (Gómez-Ortiz et al., 2009).

A wide variety of periglacial, nival and gravity deposits are found at this recently deglaciated site (Gómez-Ortiz et al., 2001). In addition, on the Veleta cirque there is the sole rock glacier active at present in Sierra Nevada. This rock glacier is seated on fossil relict ice and permafrost, which is the main subject matter of this article. Preliminary data are available, their dynamics and evolution, showing the progressive degradation of sedimentary icy bodies (Gómez-Ortiz et al., 2008; Sanjosé et al., 2007). This rock glacier is the main subject under study in this article, whose aims are as follows:

(a) to analyse the temperature of the ground at the heart of the rock glacier

(b) to determine the extent and evolution of the underlying frozen mass

(c) to analyse the role of snow in the thermometry of the ground

(d) to evaluate the degradation process of the relict fossil ice and permafrost in the eastern third of the Veleta cirque (Fig. 1) and what parameters triggered this degradation during the 2006-2013 period.

\section{Study area}

Sierra Nevada is a characteristic massif of semi-arid Mediterranean high mountains, positioned at the extreme SE of the Iberian Peninsula $\left(37^{\circ} \mathrm{N}, 3^{\circ} \mathrm{W}\right)$. Its highest stretches, from the Caballo peak ( $3011 \mathrm{~m}$ a.s.l.) to the Trevélez pass $(2799 \mathrm{~m})$, exceed $3200 \mathrm{~m}$, among which rise the summits of Mulhacén (3478 m), Veleta (3398 m) and Alcazaba (3364 m). The landscapes of these areas, seen above all through the prism of their geomorphology and botany, contributed to Sierra Nevada being declared a Biosphere Reserve (1986), Natural Park (1989) and National Park (1999).

The climate conditions dominating the highest parts of Sierra Nevada are characteristic of high mountains in subtropical latitudes, conditioned by the presence of the Mediterranean Sea to the east. Total annual rainfall at $2500 \mathrm{~m}$ is $702 \mathrm{~mm}$ and mean annual temperature, $4.4^{\circ} \mathrm{C}$ (Oliva et al., 2008). At the peaks ( $>3300 \mathrm{~m}$ ) mean annual temperature is around $0{ }^{\circ} \mathrm{C}$ (Gómez-Ortiz et al., 2012a). These are dry, cold mountains characterised by a very long winter season with major snowfall, contrasting with a short, arid summer.

These mountains consist of a robust massif of Alpine age, with its main axis some $35 \mathrm{~km}$ from the Mediterranean. The axial sector of this massif has been fashioned in Palaeozoic feldspathic micaschists which are greatly affected by its Alpine tectonics (Sanz de Galdeano and López-Garrido, 1998). Of the relief and sculpting of Sierra Nevada, its glacial traces, shaped during Quaternary cold periods and the LIA, and its periglacial traces, today still active at the highest parts, should be highlighted. Evidence of these processes, abundant at the heads of ravines and at the top of mountain slopes, lies in the erosion and deposition seen. The main examples of the former are the glacial cirques and overexcavation basins (e.g. Dílar, Guarnón, Valdeinfierno, Caldera, Río Seco) and of the latter, the moraines in valleys and the rock 

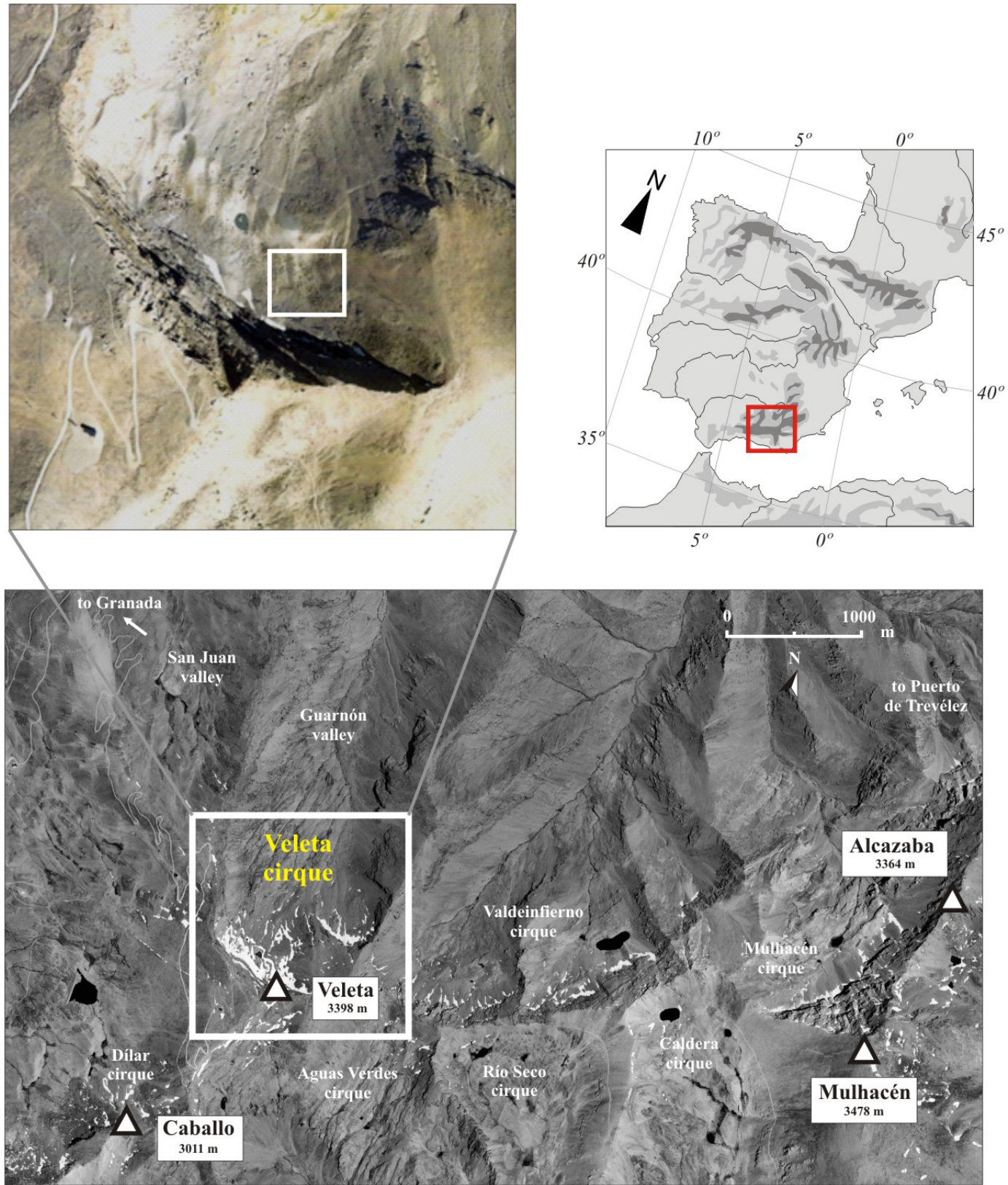

Figure 1. Sierra Nevada peaks and location of the Corral del Veleta.

glaciers in the hollows of glacial cirques (e.g. Dílar). Of outstanding interest because of its environmental and geomorphological significance is the rock glacier lodged in the eastern sector of the Veleta cirque (source of the Guarnón river) (Fig. 1). Its formation is very recent and its detritus sits on remains of glacial ice and permafrost from the last centuries in the process of degradation (Gómez-Ortiz et al., 2001).

All over the mountains, above $2650 \mathrm{~m}$ as the mean height, cryonival morphogenic processes dominate. In these sectors the combination of cold, ice, wind and snow impedes the formation of soil and the rooting of vegetation. Psychroxerophilous open, low-lying pastures tend to form, as occurs in what is known as the cryo-Mediterranean layer, with the presence of species such as Festuca clementei and Artemisia granatensis. However, at those sites where snowmelt waters last through the summer (bottoms of ravines and lake environments in cirque areas), hydrophile pasture is the dominant plant form, including, as the heirs to the quaternary climate crises, significant endemic species (Ranunculus acetosellifolius, Festuca pseudoeskia, Plantago nivalis, Viola crassiuscula, Saxifraga nevadensis, Centranthus nevadensis, Artemisia granatensis, etc.). These are exceptional sites in Sierra Nevada, particularly because of their palaeo- 
environmental and ecological significance (Molero-Mesa et al., 1992; Fernández-Calzado and Molero-Mesa, 2011).

The coexistence of the sculptured shapes and the grassy carpet described, to which we should add the centuries-old traces of human activity in the area of the Sierra Nevada's peaks, usually the use of grazing land and channelling of waters, gives this part of the mountain an important heritage value. This is due to its scientific significance, as its natural systems reflect recent geological and palaeoenvironmental history, and its cultural significance, faithful witness of its villages' ways of life in recent historical periods (GómezOrtiz et al., 2013).

The fossil or relict ice and permafrost that still survives in Sierra Nevada are located on the Veleta cirque, at the foot of the Veleta peak (Gómez-Ortiz et al., 2001). These stillsurviving remains of frozen bodies are the heir of the Little Ice Age period (14th-19th centuries), although their formation may have started earlier, even during the Medieval Warm Period (Oliva and Gómez-Ortiz, 2012). Evidence of this cold phase is found in historical documents (GómezOrtiz et al., 2009; Rodrigo et al., 2012), palynological studies (Esteban-Amat, 1996) and sedimentological records (Oliva and Gómez-Ortiz, 2012; Oliva et al., 2011). Sierra Nevada was dominated by a climate regime different from today's, especially in its temperatures, which are calculated as at least $0.93{ }^{\circ} \mathrm{C}$ lower than now (Oliva and Gómez-Ortiz, 2012), which would mean that a greater altitude range was under cryonival conditions than today. These climate circumstances favoured the development of small glaciers at the tops of the high north-facing valleys of the Sierra, always above $2900 \mathrm{~m}$.

From the 17 th century on, there are accurate documents on these glacial points. Recently the study of lake sediments in the Mosca lake, in the Mulhacén Valley, has also provided precise evidence (Oliva and Gómez-Ortiz, 2012). Of all the glacial points that must have existed (Madoz, 1849, 1987), the most important one was the one in the Veleta cirque, which lasted until the second half of the 20th century (García-Sainz, 1947) and about which we possess accurate accounts from the 18th century on. It was then described by Ponz (1797) as follows:

[...] the nearby site called Veleta cirque, name that fits its proportions, as it is a wide and closed depth with very sheer cliffs and no entry anywhere, enormous receptacle of snow, which is believed to hold the first that fell after the Deluge, reduced to stone, as its being open to the north, here is ice what in other parts is snow; and it never melts except on the surface, which is where the Sun touches it.

However, it was Boissier $(1837,1995)$ who classified it as a glacier:

The glacier has a very steep slope, its perpendicular height measures 200 to 300 feet, its width more or less 600 steps [...] It has the peculiarity of being the only one in the entire Sierra and the most southerly in Europe: it owes its formation to its position, at the bottom of a sheltered cirque, surmounted on all sides by the high summits where the storms sweep the snow in winter [...] it presents in miniature all the characteristics of Alpine glaciers, clefts, impure ice, muddy moraines $[. .$.$] .$

And Bide (1893) marks it as a glacier on his map synthesising the valleys of Sierra Nevada.

From the last decades of the 19th century, the glacial point in the Veleta cirque, like all the other points on the massif, entered a process of confinement, with its ice being steadily cornered towards the eastern third of the base of the Corral, in contact with the incline of the Collado de los Machos (Gómez-Ortiz et al., 2003). Among the final references to these glacial ices are those of Solé-Sabarís (1942) and García-Sainz (1947), who report on their smallness and physical features. From the second half of the 20th century, taking these latter reports as references, the remaining ice must have been steadily more and more confined under the rock packs of blocks detached from the wall of the Veleta cirque, with the entire glacial body evolving towards a black glacier and then drifting to a rock glacier, defined as a glacier-derived rock glacier (Johnson, 1987; Humlum, 2000; Fort, 2003).

At present in the Veleta cirque there are no visible remains of those glacial ices, although the morphogenetic processes that dominate are high-mountain periglacial processes, very close to paraglaciers. In particular, this occurs in the eastern third, at the bottom and the adjoining detritic slope, which is where the frozen masses still persist and where the processes linked to snowmelt and degradation of levels of permafrost or "lentils" of ice trapped among the scree create instability (Gómez-Ortiz et al., 2008; Tanarro et al., 2010, 2012), as is occurring in other recently deglaciated mountain environments in central Iberia (e.g. Palacios et al., 2003).

On the remains of the glacial ice and permafrost, starting in the mid-20th century, a rock glacier was created, which is the main subject of our study (Fig. 2). This periglacial landform is located in the eastern third of the Veleta cirque, at a mean altitude of $3106 \mathrm{~m}$. It is $129.6 \mathrm{~m}$ long, with an average width of $37.5 \mathrm{~m}$, a mean thickness measured against the slope of about $8 \mathrm{~m}$ and a total surface area of $3815 \mathrm{~m}^{2}$. The mean gradient on the front stretch is $15.5^{\circ}$, which reduces to $8^{\circ}$ in the middle stretch and increases to $23^{\circ}$ in the higher stretch.

\section{Materials and methods}

In recent years the morphogenetic evolution of this incipient rock glacier at the base of the Veleta cirque has been monitored systematically with field-work campaigns conducted annually on the same summer dates, always in the last week of August. This article reports and discusses the results for the period 2006-2013. To analyse the process of degradation 


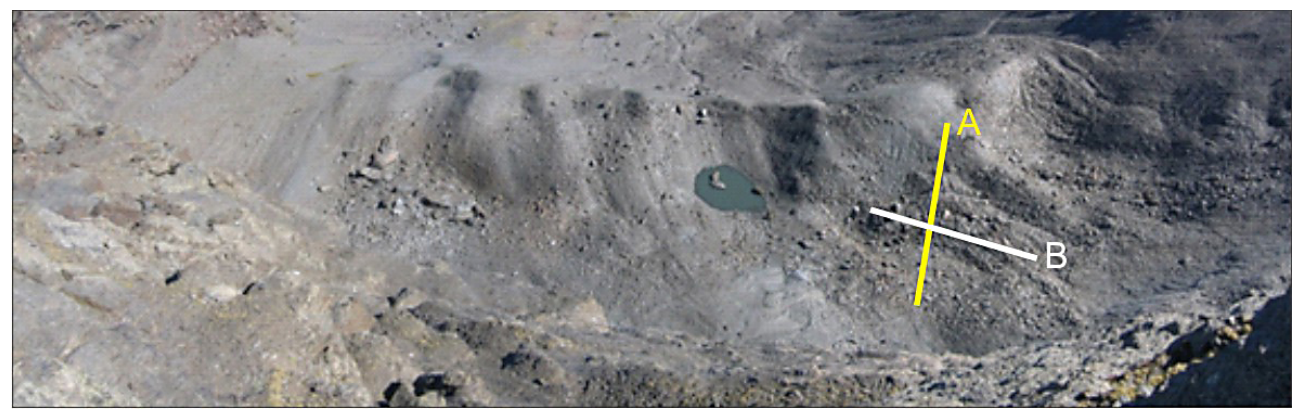

Figure 2. Distribution of the geophysical prospection transects conducted across the rock glacier in the eastern third of the Corral del Veleta.

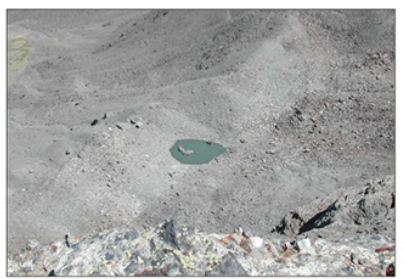

2006

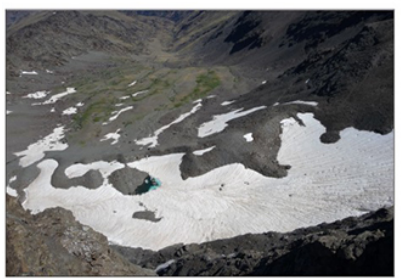

2010

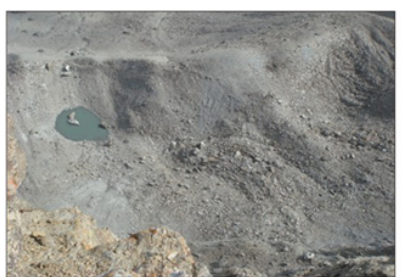

2007

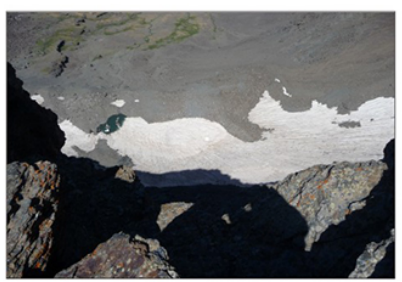

2011

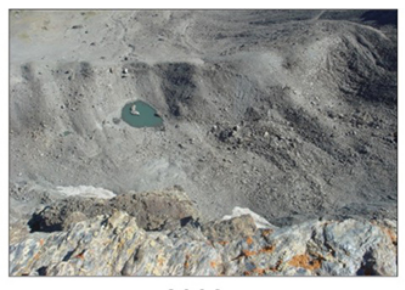

2008

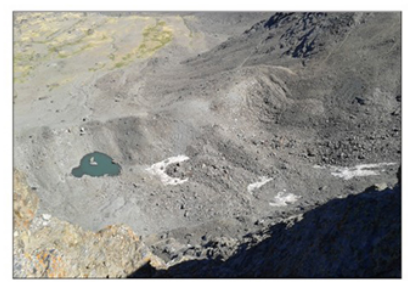

2012

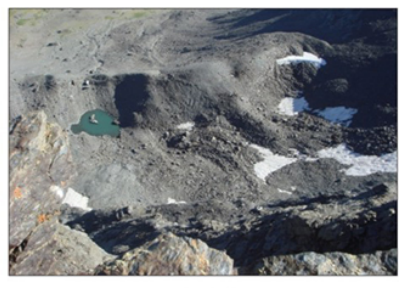

2009

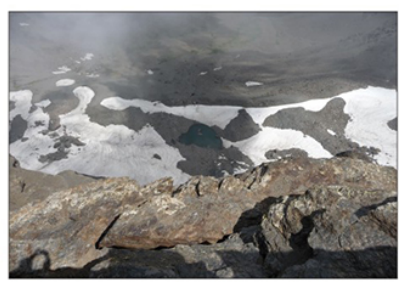

2013

Figure 3. Vertical photographs of snow cover on the Corral del Veleta at the end of August from 2006 to 2013.

of the frozen masses at the heart of the rock glacier, a series of techniques from different disciplines were employed:

(a) The degree of snow cover on the entire Veleta cirque in summer

The snow cover at the base of this cirque was inferred from pairs of digital photographs taken from distinct points (oblique and vertical views, Fig. 3), appropriately corrected and processed with the CAD MicroStation and SIG ArcMap (georeferencing module) programmes.

(b) Thermal regime of the ground in the rock glacier and air temperature

The thermal data of the ground were obtained from data-logger-type autonomous sensors (UTL-1) installed as a chain of thermal sensors distributed in a borehole drilled on the crest of the rock glacier at depths of 2, 5, 20,50 and $150 \mathrm{~cm}$. Air temperatures were also recorded on the adjacent Veleta peak with a UTL-1 sensor. All data were taken at regular $2 \mathrm{~h}$ intervals, then treated and processed statistically. Data were downloaded and batteries were replaced annually. (c) Movement of the blocks that cover the frozen masses, measured from fixed points

The rock glacier's movement was controlled by monitoring 27 fixed points (rods) distributed all over its surface area (front stretch 6, middle stretch 13, final stretch 8). To determine the rods' planar and vertical movements, geomatic techniques were used, with complete map-making instruments and GPS, referring to nearby triangulation points (Veleta peak). Annual measurements always corresponded to the same dates at the end of August. Instrument error was around $\pm 3 \mathrm{~cm}$.

(d) Geophysical characterisation of the internal frozen masses

The geophysical prospection of the inner body of the rock glacier was done in 1998 and 2009 with electrical tomography using ABEM SAS 4000 equipment, Lund cables and $2.5 \mathrm{~m}$ mean spacing between electrodes. Longitudinal and transversal transects covered the entire surface area occupied by the rock glacier.

(e) Mechanical boring 

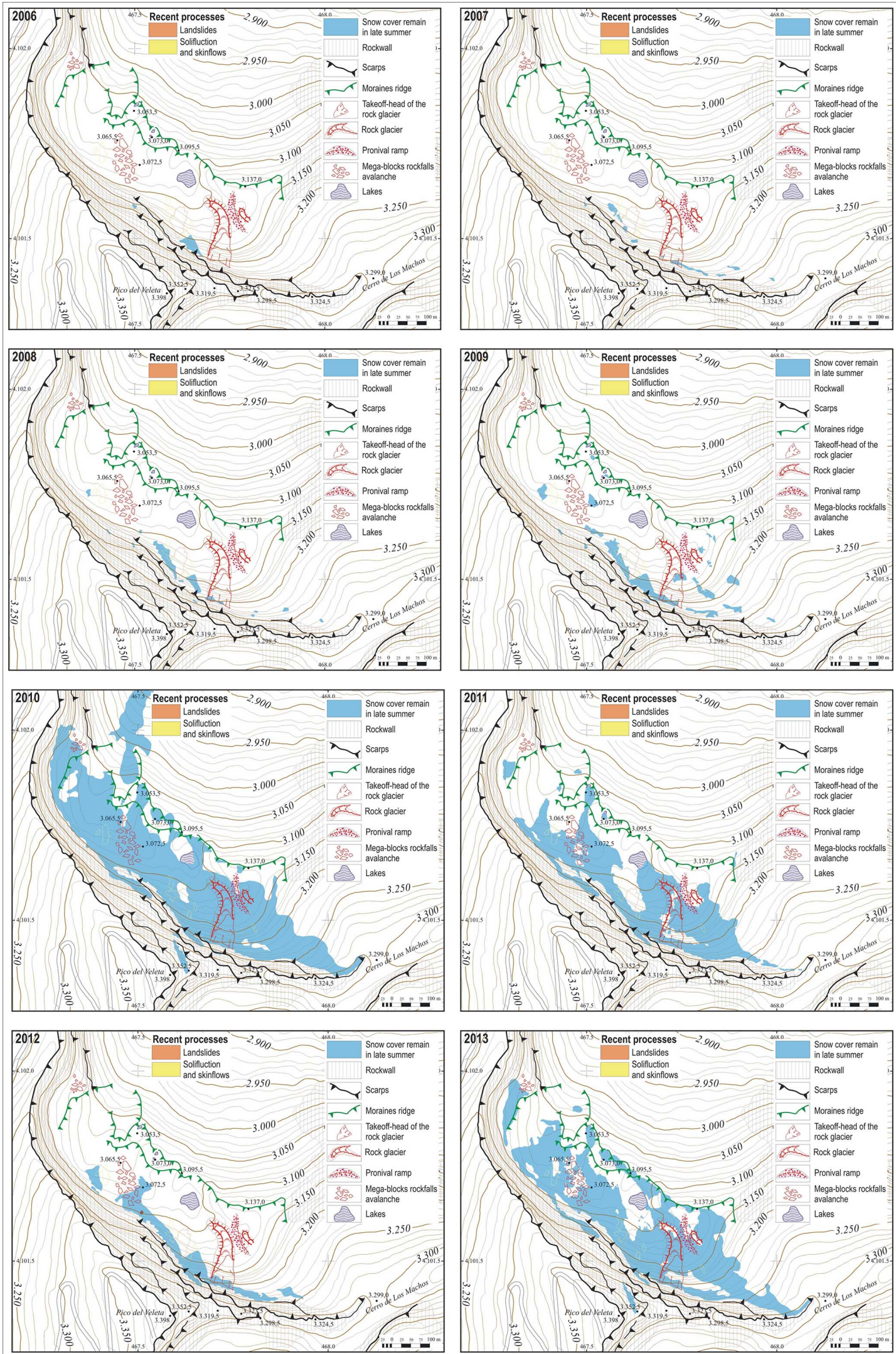

Figure 4. Ground snow cover on the Corral del Veleta at the end of August during the 2007-2011 period. 
In August 1999, under the aegis of the Permafrost and Climate Change in Europe (PACE) project, a $1.9 \mathrm{~m}$ mechanical prospection examined the middle stretch of the rock glacier, extracting a continuous core by means of an HILTI DD250D portable boring machine with a rotating penetration system and $90 \mathrm{~mm}$ diamond crown.

\section{Results}

\subsection{Snow cover of the ground}

The degree of snow cover in summer on the Veleta cirque varies a lot, conditioned by the topography of the cirque. The snow always tends to last longer against the walls that frame this cirque. Normally, from May on, it tends to melt and by August most of it has disappeared. However, in the summers of 2010, 2011 and 2013, the snow maintained over $80 \%$ cover, even exceeding $95 \%$ (Fig. 4). In the eastern sector, where the rock glacier is located, the snow also has an irregular presence. It was absent in 2007 and 2008 (Tanarro et al., 2010, 2012). In 2009 there was $15 \%$ cover and in 2012, $10 \%$, whereas in 2010 and 2011 it exceeded $95 \%$ and in 2013 was about $70 \%$, which prevented the team from carrying out its thermal and dynamic monitoring in these 3 years.

\subsection{Thermal rhythm of the ground and air}

The existence or non-existence of snow on the rock glacier during the end-of-summer campaigns conditioned the availability of thermal data on the ground at this site (Fig. 5). For the 2006-2009 period, the thawing of the active layer reached the deepest sensor, at $1.5 \mathrm{~m}$. Thermal behaviour during this period showed how this process occurs during a short window of time, starting in May-June and establishing itself by mid-July, an average window of 79 days. In these years, at $1.5 \mathrm{~m}$ depth, extreme thermal values moved between $0.7^{\circ} \mathrm{C}$ and $-2.5^{\circ} \mathrm{Cyr}$, with the annual mean at around $-1.4^{\circ} \mathrm{C}$ (Salvador-Franch et al., 2010, 2011).

The persistence of extensive and long-lasting snow cover on the Veleta cirque during 2009-2011 (Fig. 3) prevented the recovery of the sensors and the download of data during this 32-month period. In summer 2012, the temperatures were again positive in the entire ground profile, which ran in parallel with snow coverage on the rock glacier of under $10 \%$, found only at its edges. There were 76 days during which positive temperatures were recorded in the active layer.

For the 2012-2013 period, the snow again lay without interruption on the Veleta cirque from November to the end of August, although it left some spaces free on the crest and higher areas of the rock glacier, which allowed the team to take the thermal readings. Negative temperatures at depth began to be seen in October 2012 and remained constant at this figure (between $0{ }^{\circ} \mathrm{C}$ and $-2.1{ }^{\circ} \mathrm{C}$ ) until the end of $\mathrm{Au}$ gust 2013. This fact allows us to interpret that during this pe- riod the frozen mass did not suffer degradation. In this sense, at the end of August 2013 temperatures were only slightly negative in contrast to other years: at $1 \mathrm{~m}$ depth the temperature was $0.24^{\circ} \mathrm{C}$ and at $20 \mathrm{~cm}$ depth was $0.7^{\circ} \mathrm{C}$.

The average annual air temperature at the summit of the Veleta peak for the period under study was about $0.3^{\circ} \mathrm{C}$. The mean for the warmest month was $10.6^{\circ} \mathrm{C}$ in July and the coldest was $-7.5^{\circ} \mathrm{C}$ in February. For the entire year, mean monthly average temperatures were negative from November to April (average of $-5.2{ }^{\circ} \mathrm{C}$ ), although in some years they were also negative in September and May. Mean values were positive in the remaining months, with an average of $5.8^{\circ} \mathrm{C}$. There was an average of $39 \%$ of the days a year with a negative temperature, $35 \%$ of the days with positive values and $36 \%$ with alternating figures. The absolute maximum for $2006-2013$ was $28.6^{\circ} \mathrm{C}$ and the absolute minimum was $-27.8^{\circ} \mathrm{C}$.

\subsection{Movement of the rock glacier}

The movements detected at the 27 fixed reference points on the surface of the rock glacier were of two kinds: planar in favour of the slope (slippage) and vertical (subsidence/collapse) (Sanjosé et al., 2007, 2011). For the entire rock glacier, the cumulative figures for the 2006-2013 period show that subsidence predominated over slippage: $1.311 \mathrm{~m}$ against $0.428 \mathrm{~m}$ (Table 2).

The middle stretch of the rock glacier, lying on a less sloping surface, is representative of its current dynamic. The total movement of this stretch during the 2006-2013 period shows $33.1 \mathrm{~cm}$ planar advance, as against $122.9 \mathrm{~cm}$ of collapse, though with variations between years. The maximum figures for planar movement were found in 2006-2007, with $12 \mathrm{~cm}$, and the maximum vertical movement was in 2007 2008 , with $34.7 \mathrm{~cm}$. The lowest rates of planar movement occurred in 2008-2009 with $5.1 \mathrm{~cm}$ and of vertical movement, in 2011-2012 with $31 \mathrm{~cm}$. For movements in 2009-2010, 2010-2011 and 2012-2013, there are no data available, due to the considerable snow thickness on the rock glacier and its immediate surroundings on the eastern third of the Veleta cirque, which made it impossible to monitor the fixed rods.

\subsection{Physical state of the internal frozen masses}

It is relevant to highlight how the physical state and location of the internal frozen body of the rock glacier and its immediate surroundings (glacial ice and permafrost) has varied over time in its distribution and thickness. In 1998, the whole frozen mass formed continuous and relatively homogeneous packs, stretching over the entire eastern third and areas adjacent to the base of the Veleta cirque (Gómez-Ortiz et al., 1999). Within the sampled area, a borehole drilled in the central section of the rock glacier showed the presence of the permafrost table at $1.5 \mathrm{~m}$ (Table 1). 


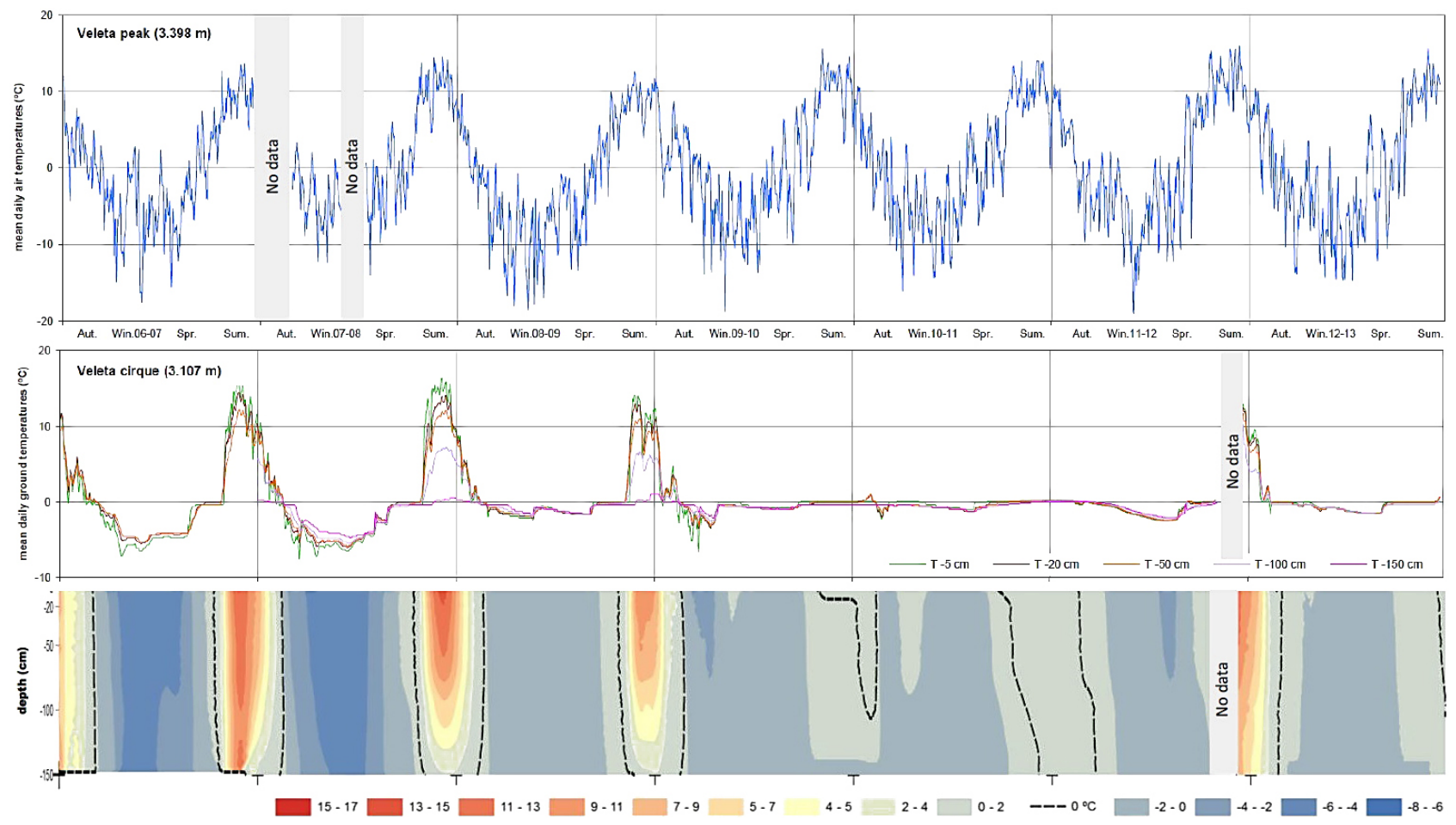

Figure 5. Annual rhythm of ground temperatures at the heart of the rock glacier for 2006-2013.

Table 1. Characteristics of the continuous core (modified from Gómez Ortiz et al., 1999).

\begin{tabular}{lll}
\hline Depth $(\mathrm{cm})$ & Material & Sedimentological and petrographic characteristics \\
\hline $0-120$ & Blocks & $\begin{array}{l}\text { Multi-sized blocks of feldspathic micaschists in the middle stretch } \\
\text { of the rock glacier. Compact structure with no alteration. }\end{array}$ \\
Amalgam of centimetre-sized micaschist clasts with gravel \\
and sands wrapped in fragments of melting ice.
\end{tabular}

The 2009 tomographic prospection showed that the highresistance structures (with values of up to $150 \mathrm{k} \Omega m$ ) were now arranged in irregularly distributed discontinuous bodies, whose ceiling tended to start at a depth of $2 \mathrm{~m}$ (Fig. 6). This highly resistive mass, with a thickness calculated at about $10 \mathrm{~m}$, can be clearly identified in profile A. However, the high resistivity in profile $\mathrm{B}$ is located from 2 to $2.5 \mathrm{~m}$ deep and extends all over the profile, except for its central stretch.

\subsection{Discussion}

Certain key ideas on the dynamic and thermal evolution of the rock glacier on the Veleta cirque can be interpreted from the findings of the various monitoring seasons in the 20062013 period. The main ones are discussed next.

\subsection{Thermal regime of the ground and its relationship with the snow cover}

The role of snow as providing thermal insulation for the ground has been widely described in other polar and mountain environments (Brown, 1973; Goodrich, 1982; Palacios et al., 2003; Zhang, 2005). In the area under study, the extreme temperature and thermal variations recorded in the air show much more contrasting values than the ground readings in the rock glacier of the Veleta cirque (Fig. 5). The greatest thermal variations on the ground occurred in the years when snow cover on the ground surface was less or non-existent (2007-2009; Fig. 7), whereas in those other years with thick and long-lasting snow cover, this contributed to stabilising temperatures at values very close to $0{ }^{\circ} \mathrm{C}$ and notably negative temperatures at greater depth (2009-2011). 

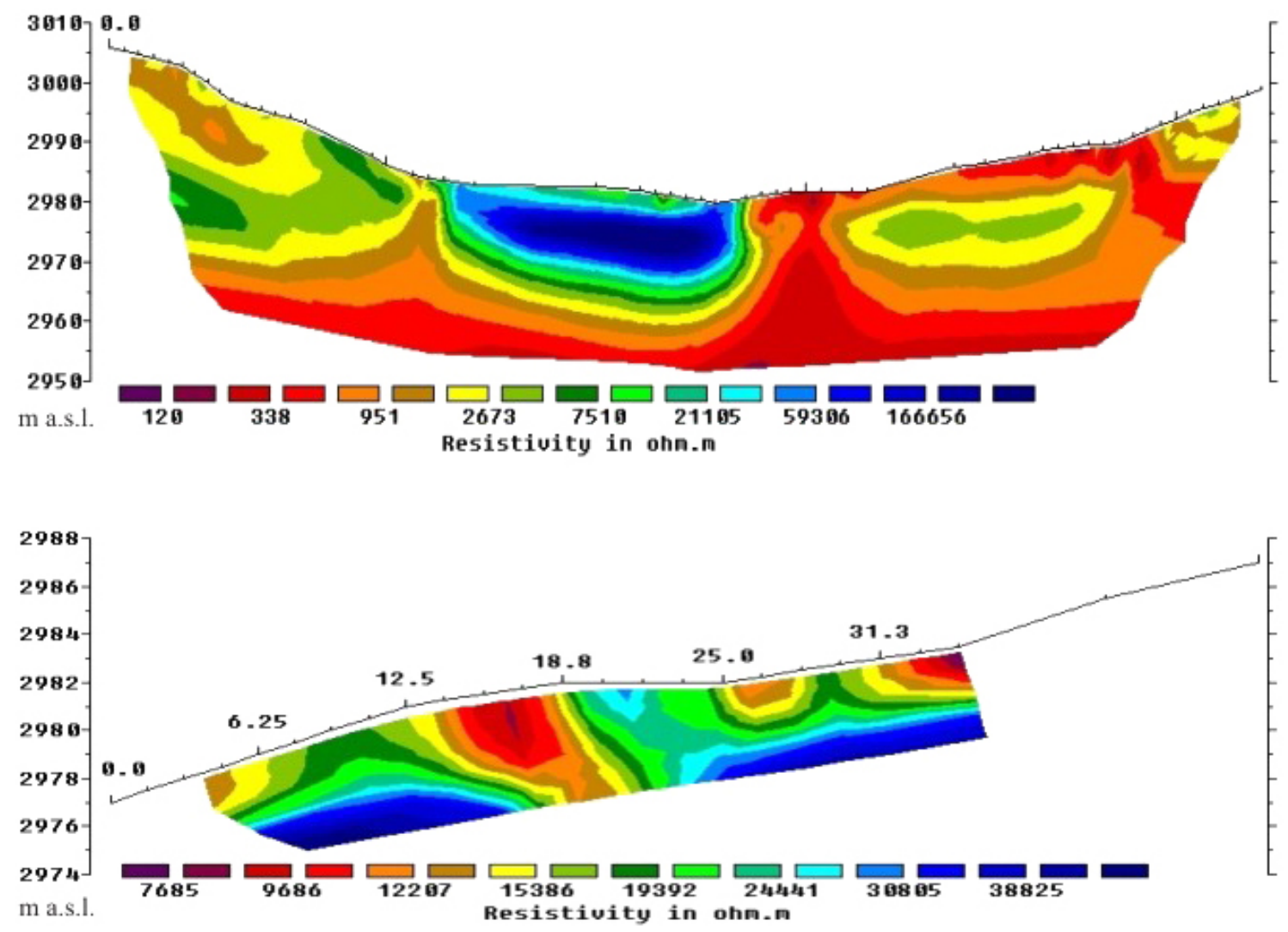

Figure 6. Geophysical prospection over the whole of transect A, transversal to the rock glacier in its middle stretch and adjacent margins (N-S; top) and transect B, longitudinal to the rock glacier (W-E; bottom) (source: Galindo-Zaldívar).

The most long-lasting negative annual temperatures were always recorded at deeper levels, especially on the sensor installed at $1.5 \mathrm{~m}$ depth, conditioned by its closeness to the upper boundary of the internal frozen ground. The data from this sensor recorded values between 0.7 and $-4.8^{\circ} \mathrm{C}$. On the contrary, the levels nearer the surface were characterised by greater thermal variation, given the greater influence of the external thermal range. For example, at $5 \mathrm{~cm}$ depth the extreme temperature range of the period was $48.2^{\circ} \mathrm{C}$ (between 28.6 and $-19.6^{\circ} \mathrm{C}$ ), with a mean annual amplitude of $27.2^{\circ} \mathrm{C}$. Regarding the logger at $1.5 \mathrm{~m}$ depth, the extreme temperature range is $13.8^{\circ} \mathrm{C}$ (between 9 and $-4.8^{\circ} \mathrm{C}$ ), with a mean annual average of $3.3^{\circ} \mathrm{C}$.

In the years with less snow cover, the thermal pattern on the ground, in light of the information obtained, can be summarised in a sequence of stages during the year:

(a) long cold episode with negative temperatures and permanently frozen ground. This starts in SeptemberOctober and lasts until mid-June.

(b) short episode with positive temperatures very much in the active layer. Its length may vary by weeks, but always coincides with the second half of the summer. (c) two very brief episodes that act as transition between the above two episodes, during which there is the shift in ground temperatures:

- from positive to negative in October and November

- from negative to positive after mid-June.

However, in those years when the snow lasted all summer, the ground temperatures were very stable at all levels, remaining very close to $0^{\circ} \mathrm{C}$ or clearly negative. Thus, from November 2009 until June 2012, the snow covered the entire surface area of the rock glacier for an uninterrupted period of 32 months, with temperatures at its heart ranging from 0.2 to $-2{ }^{\circ} \mathrm{C}$.

\subsection{Dynamics of the rock glacier and its relationship with the frozen body}

The physical behaviour and distribution at depth of the frozen masses and permafrost could be interpreted by contrasting the data from the geoelectric surveying carried out in 1998 (TERRADAT LTD and ETH, 1998) and in 2009. The results of electrical tomography profiles repeated in 2009 at the same positions as in 1998 show a reduction and disconnection of the highly resistant bodies interpreted as deep frozen 
Table 2. Planar and vertical movements (2007-2013).

\begin{tabular}{|c|c|c|c|c|c|c|}
\hline Period & Area & Dpm & Dvm & IC & Smt & SmT \\
\hline \multirow[t]{4}{*}{ 2006-2007 } & Lower & 0.160 & -0.497 & 0.068 & -0.429 & \\
\hline & Middle & 0.120 & -0.350 & 0.016 & -0.334 & \\
\hline & Upper & 0.212 & -0.495 & 0.054 & -0.441 & \\
\hline & & 0.164 & & & & -0.401 \\
\hline \multirow[t]{4}{*}{$2007-2008$} & Lower & 0.108 & -0.455 & 0.046 & -0.409 & \\
\hline & Middle & 0.073 & -0.356 & 0.009 & -0.347 & \\
\hline & Upper & 0.106 & -0.446 & 0.027 & -0.419 & \\
\hline & & 0.095 & & & & 0.391 \\
\hline \multirow[t]{4}{*}{ 2008-2009 } & Lower & 0.064 & -0.255 & 0.027 & -0.228 & \\
\hline & Middle & 0.051 & -0.244 & 0.006 & -0.238 & \\
\hline & Upper & 0.077 & -0.273 & 0.019 & -0.254 & \\
\hline & & 0.064 & & & & -0.240 \\
\hline 2009-2010 & & $\mathrm{Nd}$ & $\mathrm{Nd}$ & $\mathrm{Nd}$ & $\mathrm{Nd}$ & \\
\hline 2010-2011 & & $\mathrm{Nd}$ & $\mathrm{Nd}$ & $\mathrm{Nd}$ & $\mathrm{Nd}$ & \\
\hline \multirow[t]{4}{*}{ 2011-2012 } & Lower & 0.078 & -0.189 & 0.033 & -0.156 & \\
\hline & Middle & 0.087 & -0.321 & 0.011 & -0.310 & \\
\hline & Upper & 0.150 & -0.410 & 0.038 & -0.372 & \\
\hline & & 0.105 & & & & -0.279 \\
\hline 2012-2013 & & $\mathrm{Nd}$ & $\mathrm{Nd}$ & $\mathrm{Nd}$ & $\mathrm{Nd}$ & \\
\hline Total & & 0.428 & & & & -1.311 \\
\hline
\end{tabular}

masses. This physical disconnection (Fig. 6a and b) can be interpreted from the presence of relatively conductive areas spreading vertically, adjacent to the resistive masses, which has to favour the circulation of meltwater and feed back into the internal degradation of the frozen masses.

The movement found from 2006 to 2013 (0.428 m planar movement and $1.311 \mathrm{~m}$ in vertical collapse) indicates that current climate conditions are not very favourable to the maintenance of the frozen masses trapped inside and under the rock glacier and its immediate surroundings. This leads to the interpretation that they are in an ongoing process of degradation, with repeated subsidence, settlement of the clastic pack and, logically, a steady reduction of the frozen masses.

Given the estimated thickness in 1998 of the frozen nucleus at about $20 \mathrm{~m}$ (Gómez-Ortiz et al., 1999), we can see a continuous loss of thickness and volume in the frozen mass from the end of the 1990s, given the 10 m estimated in 2009. Based on the direct interpolation of the data of collapse obtained from the 27 rods and taking the distribution of the frozen masses at depth as homogeneous and of a similar thickness, the loss of volume for 2006-2013 is calculated at $1474.8 \mathrm{~m}^{3}$ for the middle stretch of the rock glacier and at $4688.5 \mathrm{~m}^{3}$ for all of it (Table 3). These figures must be taken as estimates, as the 2009 tomography findings showed partitions in the underlying frozen mass.

The annual figure for subsidence of the rock glacier (middle stretch and all of it) is greatly conditioned by the permanence and distribution of snow on the Veleta cirque at the height of the warm season (Table 3). The degree of summer snow cover favours or hinders the efficacy of the temperature and water circulation at the heart of the ground and, consequently, the degradation of the deep frozen masses as an end result. In years with snow still present at the end of August, the degree of degradation is always less than in the years when snow disappears early, as occurred in 2006-2009. In 2010 and 2011, degradation must have been little or none, as from the start of winter 2009 the snow remained uninterruptedly at the base of the Veleta cirque. In these years snow covered over $95 \%$ of the site's total surface area, which prevented its being monitored, as also occurred in 2013.

This continuous degradation of the frozen masses described above has to be the outcome of a succession of physical knock-on effects, starting from the external radiation that reaches the ground and melts the snow (Fig. 8). The steady elimination of snow in summer means that the energy from external radiation constantly penetrates the active layer of the ground and creates positive temperatures throughout its 


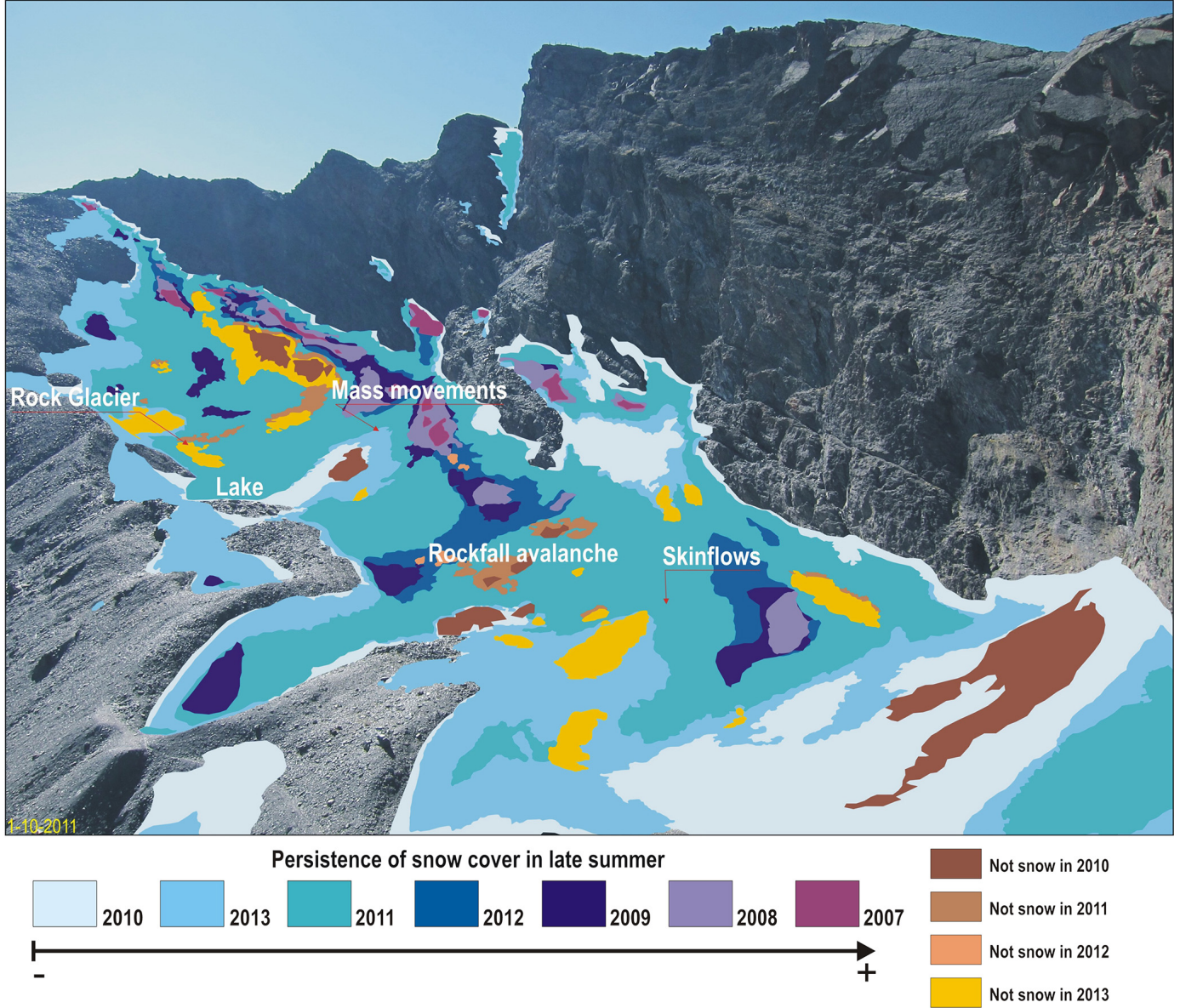

Figure 7. Evolution of snow cover on the Corral del Veleta for 2007-2011.

profile, which then reach the upper boundary of the frozen masses, tending to degrade and unfreeze them. In this entire linked process, the circulation of the meltwaters fulfils a very important task, as they act as heat transmitters. This explains the subsidence and continual resettling of the entire clastic pack and the melting of the frozen ceiling on which the pack rests. This happens in a few summer weeks, when positive ground temperatures are recorded (Fig. 5, episode T1).

\subsection{Recent evolution and future perspectives for the dynamics of the rock glacier}

The cumulative data on the physical behaviour of the frozen masses and snow cover of the Veleta cirque are still too scant to give us solid conclusions on climate. No outstanding patterns for the rainfall regime in southern Iberia have been recorded since the end of the 1970s (Oliva and Moreno, 2008; Raso, 2011). However, an increase in minimum temperatures since the 1970s has been discerned. This has been measured at $0.37^{\circ} \mathrm{C}$ a decade, keeping almost the same through the years, whereas maximum temperatures have increased less, just $0.18^{\circ} \mathrm{C}$ a decade, with greater inter-annual irregularity, especially in spring (García-Barrón, 2007), precisely the thawing season in Sierra Nevada's peaks. Thus, the climate conditions that predominate on the summits of this massif are not favourable to snow remaining permanently on the ground. The spatial distribution of late-melting refrigerated points shows their steady retreat to ever-higher levels and a predilection for topographical sites safeguarded from radiation and, in the case of south-facing sites, for dips to leeward (Gómez-Ortiz et al., 2012a).

In geomorphological terms, the start of this climate situation that is adverse to the maintenance of snow on the ground in summer goes back to the second half of the 19th (Oliva et al., 2009, 2011) and the start of the 20th century and still more so from the mid-20th century on (Solé-Sabarís, 1942; García-Sainz, 1947). This is the time when the historical glacier existing on the Veleta cirque began to shrink rapidly, tending to survive more toward the east in the shelter of the Machos slope and increasingly covered by scree from the destruction of the walls of the cirque itself, which is the origin of the current rock glacier (Gómez-Ortiz et al., 2003).

The greater exposure of the rock glacier to radiation, due to less protection by snow cover during the last decades of 
Table 3. Synthesis of values for movement (middle stretch of the rock glacier), loss of volume, snow cover and days with positive temperature.

\begin{tabular}{|c|c|c|c|c|c|c|}
\hline Period & $\begin{array}{r}\text { Planar } \\
\text { displacement } \\
(\mathrm{m})\end{array}$ & $\begin{array}{r}\text { Vertical } \\
\text { displacement } \\
(\mathrm{m})\end{array}$ & $\begin{array}{r}\text { Volume } \\
\text { loss } 1 \\
\left(\mathrm{~m}^{3}\right)\end{array}$ & $\begin{array}{r}\text { Volume } \\
\operatorname{loss}^{2} \\
\left(\mathrm{~m}^{3}\right)\end{array}$ & $\begin{array}{r}\text { Snow cover } \\
\text { in the ground } \\
(\%)\end{array}$ & $\begin{array}{r}\text { Days with } \\
\text { positive soil } \\
\text { temperatures }\end{array}$ \\
\hline 2006-2007 & 0.120 & -0.334 & 400.8 & 1274.2 & 0 & 85 \\
\hline 2007-2008 & 0.073 & -0.347 & 416.4 & 1323.8 & 0 & 84 \\
\hline 2008-2009 & 0.051 & -0.238 & 285.6 & 907.9 & $>15$ & 68 \\
\hline 2009-2010 & $\mathrm{Nd}$ & $\mathrm{Nd}$ & $\mathrm{Nd}$ & $\mathrm{Nd}$ & $>95$ & $\mathrm{Nd}$ \\
\hline 2010-2011 & $\mathrm{Nd}$ & $\mathrm{Nd}$ & $\mathrm{Nd}$ & $\mathrm{Nd}$ & $>95$ & $\mathrm{Nd}$ \\
\hline 2011-2012 & 0.087 & -0.310 & 372.0 & 1182.6 & $<10$ & 76 \\
\hline 2012-2013 & $\mathrm{Nd}$ & $\mathrm{Nd}$ & $\mathrm{Nd}$ & $\mathrm{Nd}$ & $>70$ & 0 \\
\hline Total & 0.331 & -1.291 & 1474.8 & 4688.5 & & \\
\hline
\end{tabular}

${ }^{1}$ Referring to the middle stretch of the rock glacier, occupying a surface area of $1200 \mathrm{~m}^{2} .{ }^{2}$ Referring to the entire rock glacier, occupying a surface area of $3,815 \mathrm{~m}^{2} .{ }^{3}$ Referring to the eastern third of the base of the cirque. ${ }^{4}$ Referring to 183 days in all (61 in September and October and 122 from May to August); Nd: no data.

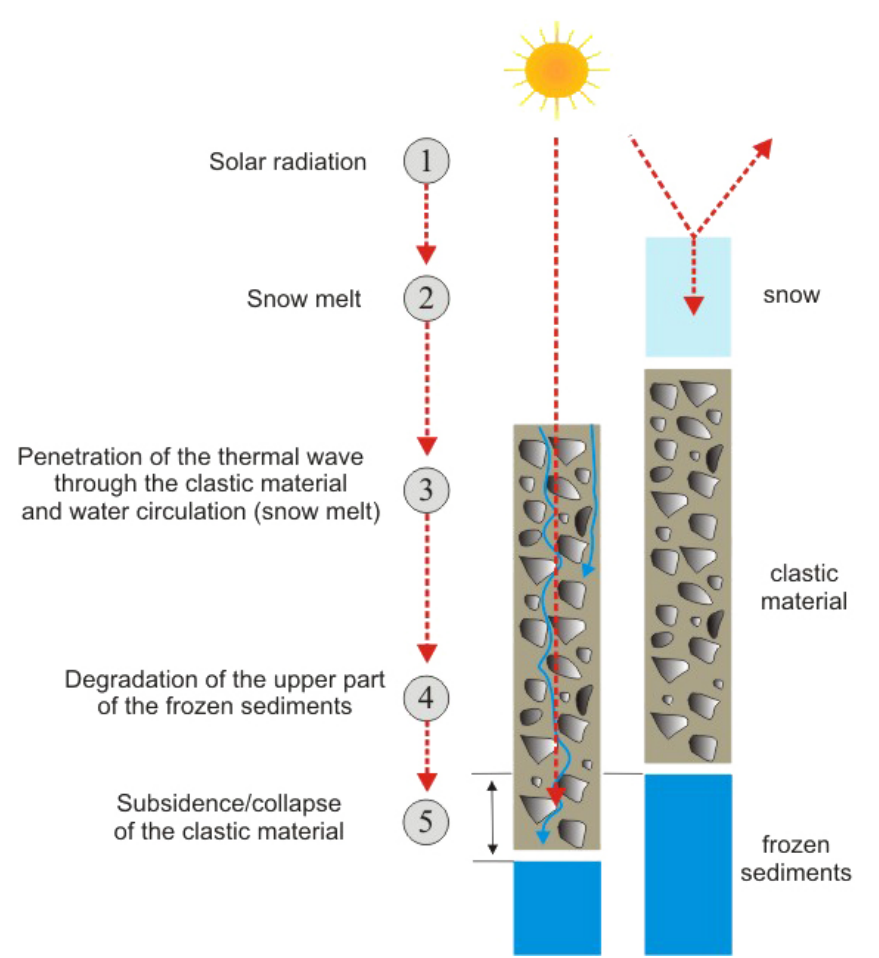

Figure 8. Interpretative diagram of the knock-on physical processes.

the 20th century has favoured the gradual degradation of the frozen masses on which it sits, with repercussions on its morphodynamics, which translates above all into the high figures for subsidence or collapse against much lower figures for its advance. The thermal increase recorded during these last decades in the south of the Iberian peninsula and the shorter time that snow lasted on the ground, especially in summer, might be the origin of this behaviour of the rock glacier, involving an accelerated process of stabilisation and settle- ment of its clastic pack, in response to the gradual reduction of the underlying frozen masses. This trend will presumably become more accentuated, judging by the climate projection of the IPCC (2007), which sets a temperature increase for southern Iberia in the range of 2 to $6^{\circ} \mathrm{C}$ and a 20 to $30 \%$ drop in rainfall.

This marked tendency to destabilisation in Sierra Nevada appears to be beginning to be visible in the Pyrenees, where its rock glaciers still show greater planar than vertical movement (Serrano et al., 2006, 2010; Sanjosé et al., 2007, 2011). In other ranges in the Mediterranean Alpine fringe, such as broad sections of the Alps, this positive thermal inertia recorded in recent decades has resulted in increased rates of movement of the rock glaciers, even leading to collapses and landslides in their detritus structure (Ikeda et al., 2003; Roer et al., 2005; Kääb et al., 2007; Delaloye et al., 2010). This process of degradation of permafrost has been seen for years in rock glaciers in various sectors of the Andes (Francou et al., 1999; Monnier and Kinnard, 2013) and in the final stretches of stabilised glacial tongues covered with stone blocks, as is occurring in several valleys in central Chile's Andes (Ferrando-Acuña, 2014).

\section{Conclusions}

The reconstruction of the glacial and periglacial activity that has occurred at the summits of Sierra Nevada in recent millennia demonstrates the great climate sensitivity of this massif to climate variability occurring in the North Atlantic and the extreme western fringe of the Mediterranean basin during the Holocene (Oliva et al., 2011; Oliva and Gómez-Ortiz, 2012). Then in turn, the evolution of recent observed behaviour on the rock glacier situated in the eastern third of the Veleta cirque indicates the high sensitivity of this recently deglaciated cirque. This is an invitation to consider the suitability of this site for studying the repercussions of 
recent climate dynamics on Mediterranean high-mountain ecosystems.

The electrical tomographies conducted in 1998 and 2009 make clear the presence of high-resistivity bodies linked to a frozen body beneath the existing rock glacier on the Veleta cirque. Its extension in space between these two dates shows a clear reduction in volume and the physical partition of the underlying frozen mass. A core extracted from this site enabled us to define this body as a succession of fossil ice descended from the former glacier and a frozen pack of permafrost formed as a consequence of the physical contact of the detritic mass with the overlying sediments (Gómez-Ortiz et al., 1999).

The dynamic monitoring in the 2006-2013 period made clear that these relict glacial masses and permafrost were undergoing a continuous process of degradation. The consequence of this sub-surface degradation is seen in the repeated subsidence and collapses visible on the surface of the strata of clasts that make up the rock glacier. The interpretation we make of these events is the result of the succession of knock-on physical processes, starting with the external radiation that affects the ground and reaches the ceiling of the frozen masses, especially since the surface of the rock glacier is freed from snow cover and meltwaters run through the active layer. These frozen masses suffer degradation in a few summer weeks, and much more obviously and rapidly since the snow has tended to lie for less time on the summits of Sierra Nevada, already a decades-old phenomenon.

The greater or lesser duration of snow cover on the rock glacier of the Veleta cirque determines the degree of annual collapse, which at all events was always greater than planar movement in the 2006-2013 period. During the years with greater snow presence in summer in this cirque, the subsidence figures were lower than in the 2009-2010, 2010-2011 and 2012-2013 periods, when the snow remained continuously on the ground of the Veleta cirque. In these circumstances, as the body of the rock glacier remained frozen, the underlying frozen mass did not shrink. These events entail a change in the climate trend of these recent years though how it will evolve we do not know, which means it is important to continue with the monitoring undertaken so far.

Acknowledgements. We are grateful to the research projects 018/2007 of the Autonomous Organisation of National Parks and CSO2012-30681 from the Ministry of Economy and Competition. We also thank the Sierra Nevada National Park, its director Javier Sánchez-Gutiérrez and the park rangers, for their constant support and field logistics. We are particularly grateful to Jesús Galindo-Zaldívar and Carlos Sanz de Galdeano, of the University of Granada-CSIC, for their invaluable and effective work in the geophysical tasks of the 2009 campaign.

Edited by: P. Pereira

\section{References}

Bide, J.: Deuxième excursion dans la Sierra Nevada, Annuaire du Club Alpin Français, XX, 276-305, 1893.

Boissier, C. E.: Voyage botanique dans le midi de l'Espagne pendant l'anné 1837, Granada: Fundación Caja de Granada and Universidad de Málaga, new edition from 1995, 1845.

Boissier, E.: Voyage botanique dans le midi de 1'Espagne pendant l'année 1837, spanish version in: Boissier, C. E., Viaje botánico al sur de España durante el año 1837, Fundación Caja de Granada y Universidad de Málaga, Granada, 1995.

Brown, R. J.: Influence of climate and terrain factors on ground temperatures at three locations in the permafrost region of Canada, in: Second International Permafrost Conference, Yakutsk, URSS, North American Contribution, National Academy of Science, Washington, 2115, 27-34, 1973.

Christiansen, H. H., Etzelmüller, B., Isaksen, K., Juliussen, H., Farbrot, H., Humlum, O., Johansson, M., Ingeman-Nielsen, T., Kristensen, L., Hjort, J., Holmlund, P., Sannel, A. B. K., Sigsgaard, C., Åkerman, H. J., Foged, N., Blikra, L. H., Pernosky, M. A., and Ødegård, R.: The Thermal State of Permafrost in the Nordic area during the International Polar Year, Permafr. Perigl. Proc., 21, 156-181, 2010.

Delaloye, R., Lambiel, C., and Gartner-Roer, I.: Overview of rock glacier kinematics research in the Swiss Alps, Geogr. Helv., 65, 135-145, 2010.

Esteban-Amat, A.: Evolución del paisaje nevadense durante los últimos 1500 años a partir del análisis polínico de borreguiles, in: I Conferencia Internacional Sierra Nevada, Universidad de Granada-Sierra Nevada 96, Granada, IV, 233-264, 1996.

Fernández-Calzado, M. and Molero-Mesa, J.: Historical evidences on flora composition changes in a high vegetation belt, Sierra Nevada, Spain (1837-2009), International Journal of Geobotanical Research, 1, 41-54, 2011.

Ferrando-Acuña, F.: Glaciar Pirámide: glaciar rocoso-subtipo cubierto y efectos del calentamiento en la cordillera de los Andes de Chile central, Proceedings V Iberian Conference of the International Permafrost Association, in press, 2014.

Fort, M.: Are high altitude, lava stream-like, debris mixtures all rock glaciers?, A perspective fro the Western Himalaya, Zeitschrift für Geomorphologie NF, 130, 11-29, 2003.

Francou, B., Fabre, D., Pouyaud, B., Jomelli, V., and Arnaud, Y.: Symptoms of degradation in a tropical rock glacier, Bolivian Andes, Permafr. Perigl. Proc., 10, 91-100, 1999.

Gadek, B. and Leszkiewicz, J.: Influence of snow cover on ground surface temperature in the zone of sporadic permafrost, Tatra Mountains, Poland and Slovakia, Cold Reg. Sci. Technol., 60, 205-211, 2010.

García-Sainz, L.: El clima de la España cuaternaria y los factores de su formación, Secretariado de Publicaciones, Universidad de Valencia, Valencia, 1947.

García-Barrón, L.: La evolución climática en el suroeste de la Península Ibérica basada en registros instrumentales, in: El cambio climático en Andalucía: evolución y consecuencias medioambientales, Consejería de Medio Ambiente de la Junta de Andalucía, 81-95, 2007.

Gómez-Ortiz, A., Palacios, D., Ramos, M., Schulte, L., SalvadorFranch, F., and Tanarro, L. M.: Degradación de permafrost en Sierra Nevada y repercusiones geomorfológicas: el caso del Cor- 
ral del Veleta. Resultados preliminares, Boletín de la Asociación de Geógrafos Españoles, 27, 7-22, 1999.

Gómez-Ortiz, A., Palacios, D., Ramos, M., Tanarro, L. M., Schulte, L., and Salvador-Franch, F.: Location of Permafrost in Marginal Regions: Corral del Veleta, Sierra Nevada (Spain), Permafr. Perigl. Proc., 12, 93-110, 2001.

Gómez-Ortiz, A., Palacios, D., Luengo, E., Tanarro, L. M., Schulte, L., and Ramos, M.: Talus instability in a recent deglaciation area and its relationship to buried ice and snow cover evolution (picacho del Veleta, Sierra Nevada, Spain), Geografiska Annaler, Series A, Phys. Geogr., 85, 165-182, 2003.

Gómez-Ortiz, A., Palacios, D., and Ramos, M.: Permafrost, evolución de formas asociadas y comportamiento térmico en el Corral del Veleta (Sierra Nevada, España), Últimos resultados, Bol. R. Soc. Esp. Hist. Nat. (Sec. Geol.), 99, 47-63, 2004.

Gómez-Ortiz, A., Salvador-Franch, F., Sanjosé, J. J., Palacios, D., Schulte, L., and Atkinson, A.: Evolución morfodinámica de un enclave montañoso recién deglaciado: el caso del Corral del Veleta (Sierra Nevada), "consecuencia del Cambio Climático", Scripta Nova. Revista Electrónica de Geografía y Ciencias Sociales, XII, 270, http://dialnet.unirioja.es/servlet/ articulo?codigo $=3159787,2008$.

Gómez-Ortiz, A., Palacios, D., Schulte, L., Salvador-Franch, F., and Plana-Castellví, J.A.: Evidences from historical documents of landscape evolution after Little Ice Age of a Mediterranean high mountain area, Sierra Nevada, Spain (eighteenth to twentieth centuries), Geografiska Annaler, Series A, Phys. Geogr., 91, 279-289, 2009.

Gómez-Ortiz, A., Oliva, M., Salvador-Franch, F., Salvà-Catarineu, M., Santos, B. M., Plana-Castellví, J. A., Espinar-Moreno, M., García-Ruiz, A. L., Sánchez-Gómez, S., and Serrano-Giné, D.: El paisaje reciente de Sierra Nevada. Documentos escritos de época y significado geográfico de la Pequeña Edad del Hielo, Nimbus, 29/30, 305-319, 2012a.

Gómez-Ortiz, A., Palacios, D., Palade, B., Vázquez-Selem, L., and Salvador-Franch, F.: The deglaciation of the Sierra Nevada (Southern Spain), Geomorphology, 159/160, 93-105, 2012 b.

Gómez-Ortiz, A., Oliva, M., Salvà-Catarineu, M., and SalvadorFranch, F.: The environmental protection of landscapes in the high semiarid Mediterranean mountain of Sierra Nevada National Park (Spain): historical evolution and future perspectives, Appl. Geogr., 42, 227-239, 2013.

Goodrich, L. E.: The influence of snow cover on the ground thermal regime, Can. Geotech. J., 19, 421-432, 1982.

Humlum, O.: The geomorphic significance of rock glaciers: estimates of rock glacier debris volumes and headwall recession rates in West Greenland, Geomorphology, 35, 41-67, 2000.

Ikeda, A., Matsuoka, N., and Kääb, A.: A rapidly moving small rock glacier at the lower limit of the mountain permafrost belt in the Swiss Alps, in: 8th International Conference on Permafrost, Zurich, Swets and Zeitlinger, Lisse, 455-460, 2003.

IPCC Intergovernmental Panel on Climate Change: Climate Change 2007: Synthesis Report, World Meteorological Organization, Geneva, 104 pp., 2007.

Ishikawa, M.: Thermal regimes at the snow-ground interface and their implications for permafrost investigation, Geomorphology, 52, 105-120, 2003.

Johnson, P. G.: Rock Glacier: glacier debris systems or highmagnitude low frequency flows, in: Rock Glaciers, edited by:
Giardino, J., Shoroeder, J. and Vitek, J. D., Allen and Unwin, London, 175-192, 1987.

Kääb, A., Frauenfelder, R., and Roer, I.: On the response of rock glacier creep to surface temperature increase, Glob. Planet. Change, 56, 172-187, 2007.

Lawrence, D. M., Slater, A. G., Tomas, R. A., Holland, M. M., and Deser, C.: Accelerated Arctic land warming and permafrost degradation during rapid sea ice loss, Geophysical Research Letters, 35, L1150, doi:10.1029/2008GL033985, 2008.

Löffler, J., Pape, R., and Wundram, D.: The climatologic significance of topography, altitude and region in high mountains. A survey of oceanic-continental differentiations of the Scandes, Erdkunde, 60, 15-24, 2006.

Lugon, R., Delaloye, R., Serrano, E., Reynard, E., Lambiel, C., and González-Trueba, J. J.: Permafrost and Little Ice Age relationships, Posets massif, Central Pyrenees, Spain, Permafr. Perigl. Proc., 15, 207-20, 2004.

Madoz, P.: Sierra Nevada, in: Diccionario geográfico-estadísticohistórico de España y sus posesiones de ultramar, XIV, 379386, 1849, facsimile edition: volumen Granada, Editoriales Andaluzas Unidas-Ámbito, Valladolid, 1987.

Molero-Mesa, J., Pérez-Raya, F., and Valle-Tendero, F.: Vegetación. Vegetación climácica, in: Parque Natural de Sierra Nevada. Paisaje, fauna, flora e itinerarios, Rueda, Madrid, 107-130, 1992.

Monnier, S. and Kinnard, C.: Internal structure and composition of a rock glacier in the Andes (upper Choapa valley, Chile) using borehole information and ground-penetrating radar, Annals of Glaciology, 54, 61-72, 2013.

Nelson, F. E., Anisimov, O. A., and Shiklomanov, N. I.: Subsidence risk from thawing permafrost, Nature, 410, 889 pp., 2001.

Nelson, F. E., Anisimov, O. A., and Shiklomanov, N. I.: Climate change and hazard zonation in the circum-Arctic permafrost regions, Nat. Hazards, 26, 203-225, 2002.

Oliva, M. and Gómez-Ortiz, A.: Late Holocene environmental dynamics and climate variability in a Mediterranean high mountain environment (Sierra Nevada, Spain) inferred from lake sediments and historical sources, The Holocene, 22, 915-927, 2012.

Oliva, M. and Moreno, I.: Sierra Nevada, nexo entre dos patrones de teleconexión: la NAO y la WeMO, in: Cambio Climático Regional y sus Impactos, edited by: Sigró, J., Brunet, M. and Aguilar, E., Publicaciones de la Asociación Española de Climatología, Serie A, 199-208, 2008.

Oliva, M., Schulte, L., and Gómez Ortiz, A.: Solifluction lobes in Sierra Nevada (Southern Spain): morphometry, process monitoring and palaeoenvironmental changes, in: 9th International Conference on Permafrost, edited by: Kane, D. L. and Hinkel, K. M., University of Alaska-Fairbanks, Fairbanks, 2, 1321-1326, 2008.

Oliva, M., Schulte, L., and Gómez-Ortiz, A.: Morphometry and Late Holocene activity of solifluction landforms in the Sierra Nevada (Southern Spain), Permafr. Perigl. Proc., 20, 369-382, 2009.

Oliva, M., Schulte, L., and Gómez-Ortiz, A.: The role of aridification in constraining the elevation range of Holocene solifluction processes and associated landforms in the periglacial belt of the Sierra Nevada (Southern Spain), Earth Surf. Process. Landforms, 36, 1279-1291, 2011.

Palacios, D., de Andrés, N., and Luengo, E.: Distribution and effectiveness of nivation in Mediterranean mountains: Peñalara (Spain), Geomorphology, 54, 157-178, 2003. 
Ponz, A.: Relación del viaje que desde Granada hizo á Sierra Nevada D. Antonio Ponz a influxo del Excmo. Sr. Marqués de la Ensenada, Mensajero económico y erudito de Granada, Granada, 1797.

Raso, J. M.: Variabilidad de las precipitaciones en Sierra Nevada y su relación con distintos patrones de teleconexión, Nimbus, 27/28, 183-199, 2011.

Rodrigo, F. S., Gómez-Navarro, J. J., and Montávez Gómez, J. P.: Climate variability in Andalusia (southern Spain) during the period 1701-1850 based on documentary sources: evaluation and comparison with climate model simulations, Clim. Past, 8, 117133, doi:10.5194/cp-8-117-2012, 2012.

Roer, I., Kääb, A., and Dikau, R.: Rockglacier acceleration in the Turtmann valley (Swiss Alps) probable controls, Norsk Geografisk Tidsskrift, 59, 157-163, 2005.

Romanovsky, V. E., Smith, S. L., and Christiansen, H. H.: Permafrost Thermal State in the Polar Northern Hemisphere during the International Polar Year 2007-2009: a synthesis, Permafr. Perigl. Proc., 21, 106-116, 2010.

Ruiz Fernández, J.: Las formas de modelado glaciar, periglaciar y fluviotorrencial del macizo Occidental de los Picos de Europa (Cordillera Cantábrica), Ph.D. thesis, Univesity of Oviedo, 298 pp., 2013.

Salvador-Franch, F., Gómez-Ortiz, A., and Palacios, D.: Comportamiento térmico del suelo en un enclave de alta montaña mediterránea con permafrost residual: Corral del Veleta (Sierra Nevada, Granada, España), in: Ambientes periglaciares, permafrost y variabilidad climática, edited by: Blanco, J. J., De Pablo, M. A., and Ramos, M., Publicaciones Universidad Alcalá de Henares, 61-68, 2010.

Salvador-Franch, F., Gómez-Ortiz, A., Salvà-Catarineu, M., and Palacios, D.: Caracterización térmica de la capa activa de un glaciar rocoso en medio periglaciar de alta montaña mediterránea. El ejemplo del Corral del Veleta (Sierra Nevada, España). Periodo de observación: 1998-1999/2008-2009, Cuadernos de Investigación Geográfica, 37, 25-48, 2011.

Sanjosé, J. J., Atkinson, A., Salvador-Franch, F., and Gómez-Ortiz, A.: Application of geomatic techniques to monitoring of the dinamics and to mapping of the Veleta rock glacier (Sierra Nevada, Spain), Zeitschrift für Geomorphologie NF, 51, 78-89, 2007.

Sanjosé, J. J., Kaufmann, V., Gómez-Ortiz, A., Serrano, E., Atkinson, A., Salvador-Franch, F., and González-Trueba, J. J.: Técnicas geomáticas aplicadas al control de los glaciares rocosos. Comparación de los glaciares rocosos de Doesen (Alpes), Posets (Pirineos) y Corral del Veleta (Sierra Nevada), Revista Cartográfica, 85/86, 45-62, 2011.
Sanz de Galdeano, C. and López-Garrido, A. C.: Nature and impact of the neotectonic deformation in the western Sierra Nevada (Spain), Geomorphology, 30, 259-273, 1998.

Serrano, E., Agudo, R., Delaloye, R., and González-Trueba, J. J.: Permafrost distribution in the Posets massif, Central Pyrenees, Norsk Geografisk Tidsskrift, 55, 245-252, 2001.

Serrano, E., Sanjosé, J. J., and Agudo, C.: Rock glacier dynamics in a marginal periglacial high mountain environment: flow, movement (1991-2000) and structure of the Argualas rock glacier. The Pyrenees, Geomorphology, 74, 286-296, 2006.

Serrano, E., Morales, C., González-Trueba, J. J., and Martín, R.: Cartografía del permafrost de montaña en los Pirineos españoles, Finisterra, 44, 45-54, 2009.

Serrano, E., de Sanjosé, J. J., and González-Trueba, J. J.: Rock glacier dynamics in marginal periglacial environments, Earth Surf. Proc. Land, 35, 1302-1314, 2010.

Solé-Sabarís, L.: II Reunión de Estudios Geográficos, Estudios Geográficos, 9, 687-726, 1942.

Tanarro, L. M., Palacios, D., Zamorano, J. J, and Gómez-Ortiz, A.: Cubierta nival, permafrost y formación de flujos superficiales en el talud detrítico de alta montaña (Corral del Veleta, Sierra Nevada. España), Cuadernos de Investigación Geográfica, 36, 39-59, 2010.

Tanarro, L. M., Palacios, D., and Gómez-Ortiz, A.: Control fotográfico de la evolución geomorfológica reciente de los movimientos en masa sobre el talud detrítico del Corral del Veleta, Sierra Nevada, España, in: Avances de la Geomorfología en España 2010-2012, edited by: González Díez, A., Ediciones de la Universidad de Cantabria, 243-246, 2012.

TERRADAT LTD and ETH: Geophysical Survey report. Permafrost Investigation Veleta and Mulhacén, Sierra Nevada. Proyecto PACE, unpublished technical report, 1998.

Yang, Z., Ou, Y., Xu, X., Song, M., and Zhou, C.: Effects of permafrost degradation on ecosystems, Acta Ecologica Sinica, 30, 33-39, 2010

Zhang, T.: Influence of the seasonal snow cover on the ground thermal regime: An overview, Rev. Geophys., 43, RG4002, doi:10.1029/2004RG00157, 2005. 